measures for obtaining oceanographical data of all descriptions in the oceans and waters adjoining their coasts, including the study of ocean currents, marine meteorology and fisheries. Having regard to the existence of the International Association of Physical Oceanography of the Sub-Committee for Oceanography of the Pacific Science Congress, however, and of various bodies dealing with marine biology and fisheries, it is doubtful whether the creation of yet another is desirable or can serve a useful purpose. The General Secretary is Señor Rafael de Buen, Alcalá, 31, Madrid.

\section{New Land Speed Record}

Sir Malcolm Campbeli set up a new motor speed record on Daytona Beach on March 7, by obtaining a speed of 276.816 miles an hour. The previous record, also set up by Sir Malcolm, on February 22, 1933, was $272 \cdot 108$ miles an hour. The figures for the time to cover the measured mile work out as follows: first run, $272 \cdot 727$ miles an hour $(13 \cdot 20$ seconds); second run, $281 \cdot 030$ miles an hour (12.81 seconds); average speed, 276.816 miles an hour. Sir Malcolm's car, Bluebird, was designed by Mr. R. Railton, and contains a 2,500 horse-power Rolls. Royce Schneider Trophy engine.

\section{Announcements}

Prof. W. N. Haworth, director of the Department of Chemistry, University of Birmingham, was elected a corresponding member of the Bavarian Academy of Sciences on February 16.

THE Bessemer Gold Medal for 1935 of the Iron and Steel Institute has been awarded to Prof. A. M. Portevin, director of the Institut de Soudure Autogène, professor at the Ecole Supérieure de Fonderie, and at the Ecole Centrale des Arts et Manufactures, Paris.

The D'Arsonval prize has been awarded by the Société française d'électrothérapie et de radiologie to the Belgian physician Dr. Etienne Hubert Henrard, for a thesis on "Short Hertzian Waves and their Medical Applications".

Prof. H. Levy will deliver a lecture on "Science and Social Responsibility" before the Institution of Professional Civil Servants on March 22 in the lecture hall, Royal Society of Arts, John Street, Adelphi, W.C.2. The chair will be taken by Mr. H. T. Tizard. Tea will be served at 5 p.m. and the chair will be taken at 5.30 p.m. Admission is free and tickets of admission are not required.

THE Royal Society of Arts has recently announced the subjects for the Thomas Gray prizes to be offered in 1935. One prize of $£ 100$ will be awarded for an "invention, publication, diagram, etc., which . . . is considered to be an advancement in the Science or Practice of Navigation". The other prize will be awarded for the best essay on "Modern Navigational Appliances." Further information can be obtained from the Secretary, Royal Society of Arts, John Street, Adelphi, London, W.C.2.
THE following appointments have recently been made by the Secretary of State for the Colonies: Mr. H. Atkinson, to be deputy Government analyst, Ceylon; Mr. J. R. E. Hindson, inspector of plants and produce, to be assistant superintendent of agriculture, Gold Coast; Mr. A. H. Malpas, assistant marine biologist, to be director, Colombo Museum, and marine biologist, Ceylon; Mr. D. B. Sabiston, deputy superintending produce inspector, to be superintendent of agriculture, Nigeria.

AT the annual general meeting of the Institute of Metals, held on March 7-8, the following officers were elected for 1935 : President, Dr. H. Moore; VicePresidents, Mr. W. R. Barclay, Dr. C. H. Desch, Dr. A. G. C. Gwyer, Prof. D. Hanson, Mr. H. C. Lancaster, Mr. F. I. Morcom ; Honorary Treasurer, Mr. John Fry.

THE Royal Astronomical Society is prepared to issue (provided sufficient support is forthcoming) a third edition of the Franklin-Adams Chart of the Sky, in 206 sheets, each covering an area $15^{\circ} \times 15^{\circ}$. The Chart is in three sections : (1) North Pole to Dec. $+22^{\circ},(2)$ Dec. $+22^{\circ}$ to $-22^{\circ},(3)$ Dec. $-22^{\circ}$ to South Pole. The price of the complete set, in three cases, has been fixed at $£ 27$, including carriage. Should any desire one or two of the sections only, subscriptions will be received for the part required at a corresponding rate. Further particulars, and application forms, may be obtained from the Assistant Secretary, Royal Astronomical Society, Burlington House, London, W.l.

Applications are invited for the following appointments, on or before the dates mentioned :-A temporary assistant engineer in the Headquarters Offices of the Ministry of Transport-The Establishment Officer, Ministry of Transport, Whitehall Gardens, S.W.1 (March 18). A lecturer (woman) in biology and nature study in the Saffron Walden Training College, Essex-The Principal (March 22). A lecturer in physiology, an assistant lecturer in mathematics, and an assistant lecturer and demonstrator in housecraft at Brighton Technical College-The Secretary, Brigh. ton Education Committee, 54 Old Steine, Brighton, 1 (March 29). A lecturer (woman) in biology and natural history in the Diocesan Training College, Derby-The Secretary (April 1). A professor of physiology in the King Edward VII College of Medicine, Singapore-The Director of Recruitment, Colonial Service, 2 Richmond Terrace, Whitehall, London, S.W.1 (April 8). Two lecturers in mechanical engineering at the Lester Technical Institute, Shanghai-The Lester Trust, c/o Messrs. Viney, Price and Goodyear, Empire House, St. Martin's-leGrand, E.C.1 (April 8). A chief mining engineer for the Northern India Salt Revenue Department - The High Commissioner for India, General Department, India House, Aldwych, W.C.2 (April 10). Assistant keepers in zoology, entomology, geology, mineralogy, and botany in the British Museum (Natural History), London, S.W.7-The Secretary (May 31). 